\title{
Habitat Use of Pacific Fishers in a Heterogeneous Post-Fire and Unburned Forest Landscape on the Kern Plateau, Sierra Nevada, California
}

\author{
Chad T. Hanson*
}

Earth Island Institute, 2150 Allston Way, Suite \#460, Berkeley, CA 94704, USA

\begin{abstract}
The Pacific fisher (Martes pennanti) is a rare forest carnivore strongly associated with dense, old forest with high canopy cover for denning and resting. The Sierra Nevada population is very small, genetically distinct, and isolated. Mixed-severity wildland fire is assumed to be a potentially greater threat than logging, and land managers are conducting large-scale forest thinning operations under the hypothesis that it is needed to reduce fire spread and severity. However, the relationship between fishers and fire has not been tested previously. I investigated this question with teams of dogs specially trained to detect the scat of Pacific fishers and, thus, their concentration of movements and habitat use. All scat samples were genetically verified. In surveys on the Kern Plateau in the southwestern Sierra Nevada, within unlogged post-fire forests with mixed-severity effects from large fires, and in unburned forests, I found that fishers selected Sierran mixed-conifer forests in both post-fire and unburned areas, and selected closed-canopied, mature/old forest in unburned forests, as well as burned forests that had this structure in the pre-fire condition. When fishers were near burned/unburned edges, they selected the within-fire side. Fishers used dense, mature/old forest that experienced moderate/high-severity fire at the same level as unburned dense, mature/old forest, and both males and females were found deep inside large fires-several $\mathrm{km}$ from the fire perimeter. These results indicate that fishers may benefit from the structural complexity of such post-fire habitat for foraging. This suggests mixed-severity wildland fire could be restored through managed wildland fire in these forests.
\end{abstract}

Keywords: Pacific fisher, Sierra Nevada, burned forest habitat, structural complexity, forest thinning, fire suppression, managed wildland fire.

\section{INTRODUCTION}

The Pacific fisher (Martes pennanti) is a rare and imperiled forest carnivore strongly associated with dense, old conifer forest for denning and resting [1-3], though foraging habitat is less well understood. The southern Sierra Nevada population of fishers is genetically distinct [4], and geographically isolated, with only 125-250 adults estimated to remain currently [5]. This species is a Candidate for listing under the Endangered Species Act at present.

Mechanical thinning operations, which remove most understory trees and many mature, older trees as well, has been found to be a threat to Pacific fishers [6], in significant part because such management substantially reduces forest density and canopy cover, while fishers select the densest forests for resting habitat [7]. Moderate- and high-severity wildland fire are believed to be a threat as well, and current management direction hypothesizes that it is a greater threat than thinning, based upon modeling that assumes an average of $\sim 90 \%$ tree mortality (high-severity fire) whenever fires occur [8-12]. The U.S. Forest Service, Region 5 (California), defines higher-severity fire $(50 \%$ of more basal area mortality from fire) as a "deforested condition" (http://www.fs. fed.us/r5/rsl/projects/postfirecondition/methods/), and currently seeks to prevent this condition on the landscape. However,

*Address correspondence to this author at the Earth Island Institute, 2150 Allston Way, Suite \#460, Berkeley, CA 94704, USA; Tel: 530-273-9290;

E-mail: cthanson1@gmail.com the relationship between fishers and mixed-severity fire has not been tested previously.

Sierra Nevada montane conifer forests, including mixedconifer forests that tend to be most prevalent in fisher home ranges [13], have a natural mixed-severity fire regime, which includes low-, moderate-, and high-severity fire effects, and high-severity patches of varying sizes [14-17]. Higherseverity fire has declined about fivefold since the early $20^{\text {th }}$ century due to fire suppression [18], and wildland fires, which are currently dominated by low/moderate-severity effects, are not increasing in severity since 1984 [19]. Thus, wildland fires remain heavily suppressed currently [20], creating a deficit in fire effects relative to natural conditions. Fire could have either positive or negative effects for fishers under two distinctly different hypotheses: positive, if natural heterogeneity and structural complexity resulting from higher-severity fire creates important foraging habitat or otherwise enhances the small mammal prey base, as has been found recently for the California spotted owl (Strix occidentalis occidentalis) [21, 22]; or negative, if higherseverity fire represents essentially a categorical loss of suitable fisher habitat, as some recent modeling studies have hypothesized [9-12]. Thus, there is a need to investigate the fisher's relationship with mixed-severity fire in order to inform any balance-of-risks assessments between potential future management paradigms: management dominated by fire suppression and mechanical thinning; or management focused on restoring mixed-severity fire through managed wildland fire and prescribed burning. 
Here, I investigated this question using dogs specially trained to detect fisher scat (and, thus, the relative concentration of fisher activity in different habitats) in a heterogeneous post-fire and unburned landscape on the Kern Plateau in the southwestern Sierra Nevada. My hypotheses were that: a) fishers would select denser, older forest areas within mixed-conifer forests (unburned and burned); and b) fishers would select fire areas, including moderate/highseverity fire patches, due to enhanced foraging opportunities.

\section{METHODS}

\section{Study Area}

The study area was a 38,400-ha area in the northern Kern Plateau on the southeastern portion of Sequoia National Forest, the majority of which has been affected by several large mixed-severity wildland fires since 2000, including the McNally fire of 2002 and the Manter fire of 2000 (Fig. 1). Less than $1 \%$ of the burned forest habitat in this area experienced post-fire logging. This landscape includes Sierran mixed-conifer forest, which tends to be dominated by white fir (http://www.dfg.ca.gov/biogeodata/Cwhr/pdfs/S MC.pdf), as well as Jeffrey pine, and lodgepole pine and red fir forests at the higher elevations. Elevation of forests in the study area ranged from $\sim 1600 \mathrm{~m}$ to $\sim 2900 \mathrm{~m}$.

\section{Surveys and Analysis}

Two scat dog teams conducted random transects across all vegetation types and structures in unburned forest and in burned forest (all fire severities) in the study area in July and November of 2012. Each team consisted of a dog specially trained to detect fisher scat, and a professional human handler, from Conservation Canines at the University of Washington's Center for Conservation Biology [23]. DNA testing of all scat samples was conducted by the genetics lab at the Center for Conservation Biology to confirm that samples were from fishers, and to identify gender [23].

All samples were swabbed and extracted in duplicate using a modified version of Qiagen's DNeasy tissue extraction kit, with negative controls included at all times. Then polymerase chain reaction (PCR) analyses were conducted in duplicate on all extracts with Qiagen's Multiplex PCR kit using two different fisher-specific markers. Two different markers were developed to provide two chances of amplification in case of degraded DNA, using mitochondrial DNA since much more is available than nuclear DNA. These species-specific mitochondrial DNA markers were developed to amplify the Pacific fisher specifically, and to ensure no overlap of non-target species. Non-target species that were tested and failed to amplify using fisher-specific markers included: marten; badger; raccoon; spotted skunk; striped skunk; red fox; grey fox; ringtail; mink and other mustelids; opossum; porcupine; and wolverine. Positive controls, as well as PCR negative controls, were also included in the PCR analyses for quality control. All PCR products were run on an ABI 3100 Genetic Analyzer to provide highly sensitive detection of DNA fragment sizes, then analyzed using GeneMarker software. Samples were confirmed as fisher if both separate DNA marker bands amplified at least three times. To identify gender, a ZFX/SRY assay was used that amplifies both the X and $\mathrm{Y}$ chromosomes. Samples were confirmed as female if the $X$ chromosome amplified at least three times, and a male if the $\mathrm{Y}$ chromosome was seen at least twice. All samples were run at least three times for gender PCR.

I determined the amount of available habitat in each forest type/structure and fire severity category, as discussed below, every $0.5 \mathrm{~km}$ along the transects.

Selection with regard to forest type and forest structure at the point detection scale $(30 \mathrm{~m} \times 30 \mathrm{~m}$ pixel within which the scat sample was found) was analyzed using a Chi-square goodness-of-fit test [24] to determine whether fishers used Sierran mixed-conifer forest and dense, mature/old forest more than expected based upon availability. Forest types analyzed were Sierran mixed-conifer, Jeffrey pine, and lodgepole pine and red fir (these two were combined because they frequently intermixed in the study area), using the California Wildlife Habitat Relationships (CWHR) data base (http://www.dfg.ca.gov/biogeodata/cwhr/). For forest structure, unburned and burned dense, mature/old forest (unburned and pre-fire CWHR 4M, 4D, 5M, 5D, and 6) were compared to forest structures dominated by smaller trees $(<28 \mathrm{~cm}$ in diameter) and/or sparser canopy cover $(<40 \%$ canopy cover) (http://www.dfg.ca.gov/biogeodata/cwhr/).

A Chi-square goodness-of-fit test was also used to determine whether fishers used the within-fire $(0-500 \mathrm{~m}$ inside fire perimeters) side of fire edges more than expected based upon availability, and to assess whether they select higher fire severity at the point scale $(30 \mathrm{~m}$ x $30 \mathrm{~m}$ pixel). Fire severity was assessed using satellite imagery (www.mtbs.gov), based upon RdNBR (Relative differenced normalized burn ratio), which compares pre-fire conditions to those at one year post-fire [25]. Low-severity fire was defined as RdNBR $<316$ (less than $\sim 15 \%$ basal area mortality), moderate-severity fire was defined as RdNBR 316-477 ( 15-50\% basal area mortality), and higher-severity fire was defined as RdNBR $>477(>50 \%$ basal area mortality) [26]. To assess whether fishers select larger spatial areas (area within 500-m radius of the scat detection location in fire areas, which necessarily excluded within-fire locations $<500 \mathrm{~m}$ from unburned edges) with greater proportions of higher-severity fire, I used a Wilcoxon-MannWhitney test [24], with the proportion of higher-severity fire within the $500-\mathrm{m}$ radii as the dependent variable, and comparing detection locations to an equal number of random locations along the transects $>500 \mathrm{~m}$ inside the fires.

\section{RESULTS}

The transects in the study area covered $197 \mathrm{~km}$ in postfire habitat, $239 \mathrm{~km}$ in unburned forest, and $23 \mathrm{~km}$ within inclusions inside the fire areas where the fires caused no changes. Some areas, particularly in the northwestern portion of the study area, proved to be very difficult to access, and much of this area was comprised of rock outcroppings, so some of this area was not surveyed. Out of 84 scat detections, 78 were confirmed to be fisher (the remainder could not be positively identified, and none were confirmed to be a different species), with 29 in the fire area and 49 in 


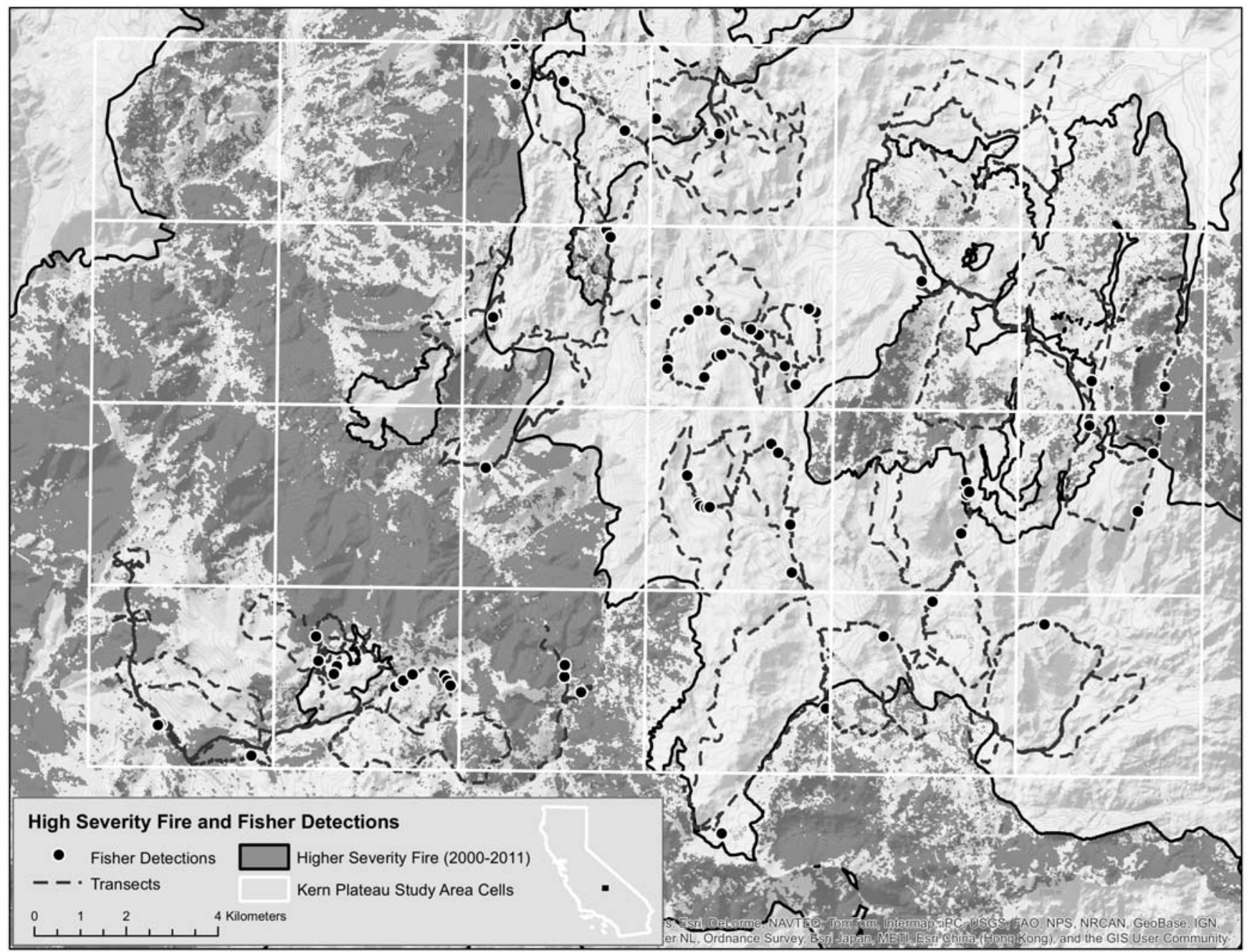

Fig. (1). The Kern Plateau Study Area, Sequoia National Forest, southwestern Sierra Nevada.

unburned forest. Fishers selected mixed-conifer forest in both post-fire habitat (Table 1a) and unburned forest (Table 1b). Within fire areas, they used pre-fire dense, mature/old forest more than expected based upon availability; the result was not significant at $\alpha=0.05$, but was significant at $\alpha=$ 0.10 , perhaps due to small sample size (Table $\mathbf{2 a}$ ). They also

Table 1a. Forest Type Use within Fire Areas (Point Scale)

\begin{tabular}{|c|c|c|c|}
\hline & RF/LP & JP & SMC \\
\hline \hline Observed & 7 & 4 & 18 \\
\hline Expected & 14.2 & 5.4 & 9.4 \\
\hline
\end{tabular}

$\chi^{2}=11.88, \mathrm{p}=0.0013(\mathrm{df}=2)$.

Table 1b. Forest Type Use within Unburned Areas (Point Scale)

\begin{tabular}{|c|c|c|c|}
\hline & RF/LP & JP & SMC \\
\hline \hline Observed & 12 & 5 & 30 \\
\hline Expected & 15.9 & 10.0 & 21.1 \\
\hline
\end{tabular}

$\chi^{2}=7.21, p=0.0136(\mathrm{df}=2)$.
Table 2a. Forest Structure Use within Burned Areas (Point Scale)

\begin{tabular}{|c|c|c|}
\hline & $\begin{array}{c}\text { Smaller and } \\
\text { Sparser }\end{array}$ & $\begin{array}{c}\text { Dense, Mature/Old } \\
(\mathbf{4 M} / \mathbf{5 M} / \mathbf{4 D} / \mathbf{5 D} / \mathbf{6})\end{array}$ \\
\hline \hline Observed & 4 & 25 \\
\hline Expected & 7.4 & 21.6 \\
\hline
\end{tabular}

$\chi^{2}=2.10, p=0.0737(\mathrm{df}=1)$.

used unburned dense, mature/old forest more than expected based upon availability (Table $\mathbf{2 b}$ ). When near a fire edge, fishers selected the within-fire side (Table 3). At the point scale (detection locations) within fire areas, fishers used

Table 2b. Forest Structure Use within Unburned Areas (Point Scale)

\begin{tabular}{|c|c|c|}
\hline & $\begin{array}{c}\text { Smaller and } \\
\text { Sparser }\end{array}$ & $\begin{array}{c}\text { Dense, Mature/Old } \\
(\mathbf{4 M} / 5 \mathrm{M} / \mathbf{4 D} / 5 \mathrm{D} / 6)\end{array}$ \\
\hline \hline Observed & 13 & 36 \\
\hline Expected & 21.3 & 27.7 \\
\hline$\chi^{2}=5.72, \mathrm{p}=0.0084(\mathrm{df}=1)$.
\end{tabular}


Table 3. Fire Edge Use (Point Scale)

\begin{tabular}{|c|c|c|}
\hline & $\mathbf{0 - 5 0 0}$ m Unburned & $\mathbf{0 - 5 0 0}$ m Burned \\
\hline \hline Observed & 6 & 9 \\
\hline Expected & 9.8 & 5.2 \\
\hline
\end{tabular}

moderate/higher-severity areas slightly more than expected based upon availability, but the result was not statistically significant (Table 4). At a larger spatial scale (500-m radius around scat detection locations) within fires, fishers selected areas with greater proportions of higher-severity fire (Fig. 2).

Table 4. Fire Severity Use (Point Scale)

\begin{tabular}{|c|c|c|}
\hline & Low & Moderate/Higher \\
\hline \hline Observed & 17 & 12 \\
\hline Expected & 18.8 & 10.2 \\
\hline
\end{tabular}

$\chi^{2}=0.49, \mathrm{p}=0.2420(\mathrm{df}=1)$.

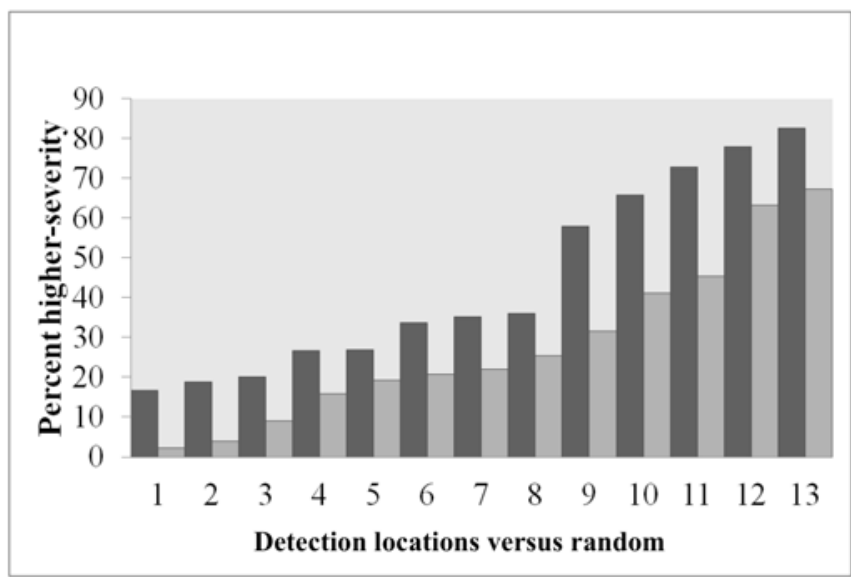

Fig. (2). Fire severity use at 500-m radius scale. Fire severity percentages within 500-m radius of detection locations (dark gray, $\mathrm{n}=13$ ), and within a 500-m radius of an equal number of random locations (light gray), entirely in fire areas are shown in ascending $\operatorname{order}(\mathrm{K}=118, \mathrm{p}=0.050)$.

Fisher scat detections $/ \mathrm{km}$ of transect length within the forest type/structure used more than available (dense, mature/old forest within Sierran mixed-conifer) were nearly identical in moderate/higher-severity burned forest $(0.326 / \mathrm{km})$ and in unburned forest $(0.327 / \mathrm{km})$.

Both males and females were detected in the fire areas, including numerous detections several $\mathrm{km}$ (and as far as 10$11 \mathrm{~km}$ ) inside the McNally fire of 2002 (Fig. 1). Gender proved to be more difficult to confirm than species. Within the fire area, gender was confirmed for 4 females and 6 males. An additional 6 samples in the fire area were possible/likely females and an additional 1 sample in the fire area was possible/likely male, but gender could not be positively determined for these. No information on gender could be obtained from the other 12 samples in the fire area. In the unburned forest, there were 5 confirmed females, and 6 confirmed males, with an additional 8 possible/likely females and 8 possible/likely males. No information on gender could be obtained for the other 22 samples in unburned forest. Of a total of 9 confirmed female samples, 3 were in unburned forest outside of the fire perimeters, 2 were inside fire perimeters within inclusions unchanged by the fires, and 4 were in post-fire habitat, which had $21 \%, 46 \%$, $72 \%$, and $83 \%$ higher-severity fire within $200 \mathrm{~m}$ of the detection location. Female fisher scat in post-fire habitat areas was detected $0.36-3.75 \mathrm{~km}$ from the nearest unburned inclusion, and 1.6-5.2 $\mathrm{km}$ from the nearest fire perimeter boundary, within the McNally fire of 2002.

\section{DISCUSSION}

The pattern of fisher detections did not evidence a categorical adverse response to large, mixed-severity wildland fires. On the contrary, these results indicate that mixed-severity fire may have some benefits for fishers. Much remains to be discovered, through further research and additional data, regarding the relationship between fishers and mixed-severity fire, including time-since-fire effects along the post-fire successional trajectory, differences in habitat use for denning/resting versus foraging, the role of structural complexity and biomass (live and dead, conifer and non-conifer) in dense, mature/ old forest that has experienced higher-severity fire, and the influence of the scale of natural heterogeneity from mixed-severity fire. Nevertheless, the results of this initial investigation cannot be reconciled with the hypothesis that moderate- or higherseverity fire simply represents a loss of suitable fisher habitat worthy of justifying landscape-level mechanical thinning, which is known to degrade or reduce fisher habitat [6]. Indeed, detection rates were approximately the same between dense, mature/old mixed-conifer forest with moderate/higher-severity fire and unburned dense, mature/old mixed-conifer, indicating that such post-fire areas represent suitable fisher habitat, and a number of detections were so deep into the McNally fire that most or all of the home ranges of these fishers may be within the fire area, given home range size [13]. Zielinski et al. [27], using fixed fisher detection stations, also found fishers deep inside the McNally fire area.

There are a few factors which could explain my results here. First, there may be a "bedroom and kitchen" effect occurring, whereby fishers tend to select unburned forest or lower-severity burned forest for denning and resting, but may select moderate/higher-severity fire areas for foraging, similar to the radiotelemetry results in the McNally fire area for another imperiled old forest species, the California spotted owl [21]. The diet of fishers is substantially comprised of taxa, including small mammal species, which tend to be associated with complex early seral forest conditions [28] comprised of montane chaparral, downed logs, snags, and natural conifer regeneration-conditions in abundance in higher-severity fire patches in the McNally fire [21]. Such post-fire habitat is rich in small mammals, and spotted owl home ranges in the McNally fire are similar to, or smaller than, those in unburned forests in the Sierra Nevada, indicating high territory fitness in mixed-severity burned forest that has not been subjected to post-fire logging [29]. 
The scat-detection approach of this study does not distinguish between fisher denning/resting locations and foraging locations, which may explain the lack of a statistically significant difference between detections in lowseverity fire areas versus moderate/higher-severity fire areas, respectively. Thus, if, within fires, fishers are preferentially selecting lower-severity areas for denning and resting, and moderate/higher-severity areas for foraging, the scat distribution may be roughly even in each of the two conditions, consistent with my findings. Further research, both on the Kern Plateau and in other areas, will help elucidate this issue.

Second, high structural complexity and biomass may be important. My results indicate that fishers benefit not from moderate/higher-severity fire in general but, rather, moderate/higher-severity fire in mature/old forest with moderate to high pre-fire canopy cover. Such areas have high structural complexity [21,30], and can have higher overall biomass (live and dead sources combined) than unburned old forest [31]. Both of these are reduced by postfire logging [32], and may be similarly diminished by mechanical thinning (Fig. 3), which tends to reduce habitat structures/features important to fishers, such as dense understory and canopy structure, and high snag and downed log density (from competition between trees in dense stands) $[1,2,33]$. While moderate- and higher-severity fire certainly reduce overstory canopy cover, they greatly accentuate structural complexity, and density, with regard to snags, downed logs, montane chaparral patches, and natural conifer regeneration patches $[21,30,34]$ (Fig. 3). The "complex early seral forest" habitat resulting from higher-severity fire is, as a result of this complexity and high biomass, rich in native biodiversity and wildlife abundance [21, 34-38]. This may help explain why fishers are not declining on the Kern Plateau [27], despite the fact that a high proportion of the forested landscape has recently experienced large, mixedseverity fires.

Third, data indicate that the montane conifer forests of the Sierra Nevada region, including mixed-conifer and ponderosa pine forests of the southern Sierra Nevada, historically (pre-fire suppression) had a mixed-severity fire regime, which included higher-severity fire as a significant component [17-18, 39-41], with occasional very large patches $[15,39-40]$. Prior to fire suppression and logging, within the range of the Pacific fisher at that time [42], early U.S. government surveyors in mixed-conifer forests documented the natural heterogeneity created by mixedseverity fire, including the juxtaposition of dense, old forest and higher-severity fire patches in old forest.

In unlogged areas prior to fire suppression in mixedconifer forests of the Sierra Nevada, Leiberg [40] noted substantial natural heterogeneity resulting from fire, which often involved dense stands of old forest adjacent to patches of standing fire-killed trees and montane chaparral with regenerating young conifers: "All the slopes of Duncan Canyon from its head down show the same marks of firedead timber, dense undergrowth, stretches of chaparral, thin lines of trees or small groups rising out of the brush, and heavy blocks of forest surrounded by chaparral." [40] (see p. 171). Early surveyors in unlogged mixed-conifer forests of
(A)

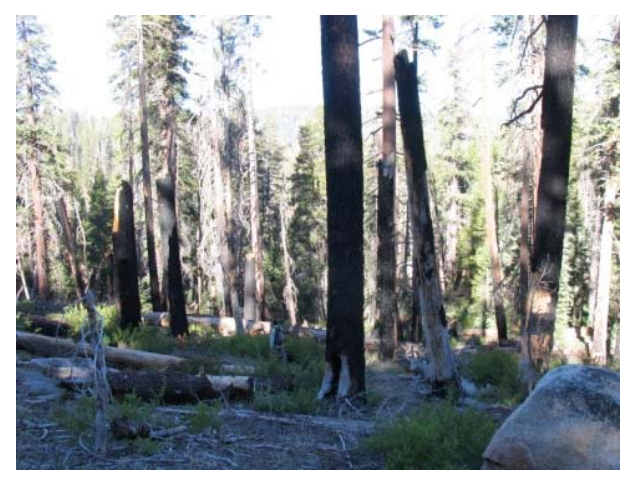

(B)

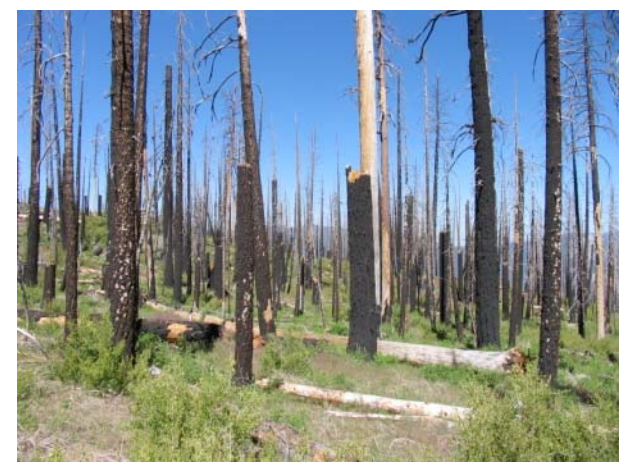

(C)

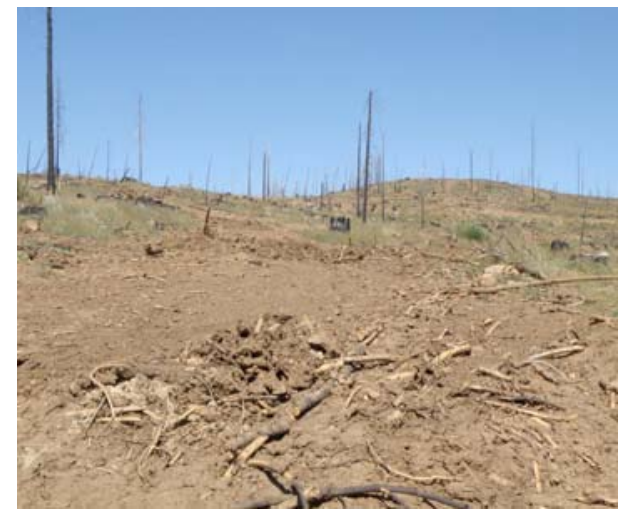

(D)

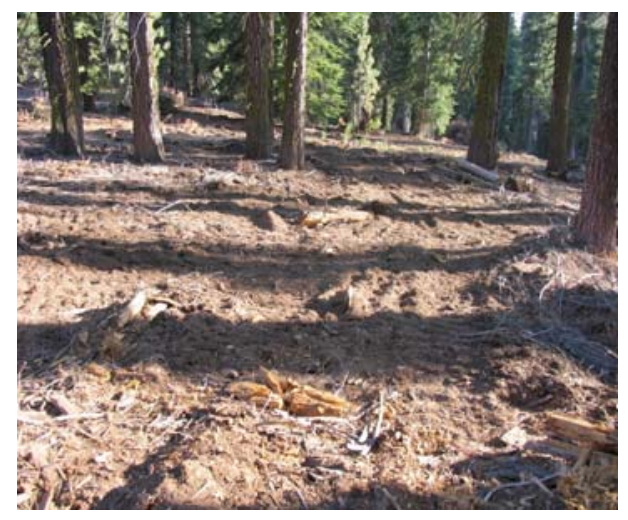

Fig. (3). Examples of varying levels of structural complexity in moderate- and higher-severity fire patches in the McNally fire of 2002 within the study area (A and B, respectively), versus post-fire logged areas (C) or mechanically thinned areas (D). 
the southern/central Sierra Nevada observed that "[s]evere fire went through [the 259-ha section being surveyed] years ago and killed most of the trees and land was reverted to brush", noting "several large dense sapling stands" [39]. Such observations were recorded for numerous 259-ha sections [39].

Similarly, Show and Kotok [15] observed that, in mixedconifer/pine forests of the Sierra Nevada, high-severity crown fires, though relatively infrequent on any particular area, "may extend over a few hundred acres" in patches [15] (see p. 31; Plate V, Fig. (2); Plate VII, Fig. (2); Plate VIII; Plate IX, Figs. $(\mathbf{1}, \mathbf{2})$; and Plate X, Fig. 1), with some highseverity fire patches covering 2,000 ha in size or more [15] (see pp. 42-43). The authors distinguished high-severity fire patches of this size from more "extensive" patches occurring in the northern Rocky Mountains [15] (see p. 31), where high-severity fire patches occasionally reach tens of thousands of ha in size, or larger, and noted that patches of such enormous size were "almost" unknown in Sierra Nevada mixed-conifer forests. In a subsequent analysis, Show and Kotok [43] found that, within the mixedconifer/pine belt of the Sierra Nevada, 1 acre out of every 7 on average was dominated by montane chaparral and young regenerating conifer forest following higher-severity fire [43] (see Footnote 2); on one national forest $\sim 87,000$ ha out of $\sim 267,000$ ha was complex early-successional habitat from severe fire [43] (see p. 17).

Thus, the fisher would have evolved with a mixedseverity fire regime - one that was much more active than it is currently $[18,20]$, and it would be adaptive to develop associations with such natural disturbance, and the prey availability there. In contrast, there is no evolutionary history for mechanical thinning or post-fire logging, which do not ecologically mimic post-fire habitat [34, 37, 44, 45].

\section{CONCLUSIONS}

The results of this study indicate that the common assumption that mixed-severity fire represents a loss of suitable habitat for fishers [9-12, 46] is unfounded, and that the relationship between fishers and fire is likely more nuanced than this. This suggests that increased use of managed wildland fire, and mixed-severity prescribed fire, in order to begin reducing the ongoing deficit in wildland fire in general [20], and higher-severity fire in particular [18, 47], would be ecologically appropriate, and should not be seen as being in conflict with fisher conservation. Even in the most long-unburned forests, current wildland fires are burning mostly at low/moderate-severity in mixed-conifer forests [48-50]. Moreover, given the extremely low current rate (long rotation intervals) of higher-severity fire, the rate of recruitment of old forest, used by fishers for denning and resting, greatly outpaces the rate of higher-severity fire in old forest in the Sierra Nevada presently [18]. Thus, even a threefold increase in higher-severity fire would reduce the current spatial coverage of old forest relatively little [18].

Given the harm to fishers that can result from mechanical thinning [6], the results of this study indicate that the balance of risks should tend to favor wildland fire over mechanical thinning in fisher habitat, contrary to the current management direction in forests inhabited by this imperiled species in the Sierra Nevada, and unlogged mixed-severity fire areas occurring within dense, mature/old forest could be incorporated into habitat connectivity models [51].

\section{CONFLICT OF INTEREST}

The author confirms that this article content has no conflict of interest.

\section{ACKNOWLEDGEMENTS}

I thank Tim Sinnott at Green InfoNetwork for the GIS work, maps, and the processing of the data for this manuscript, as well as the Environment Now foundation for their generous financial support of this work.

\section{REFERENCES}

[1] Zielinski WJ, Truex RL, Dunk JR, Gaman T. Using forest inventory data to assess fisher resting habitat suitability in California. Ecol Appl 2006; 16: 1010-25.

[2] Purcell KL, Mazzoni AK, Mori SR, Boroski BB. Resting structures and resting habitats of fishers in the southern Sierra Nevada, California. For Ecol Manage 2009; 258: 2696-706.

[3] Zhao F, Sweitzer RA, Guo Q, Kelly M. Characterizing habitats associated with fisher den structures in the southern Sierra Nevada, California using discrete return lidar. For Ecol Manage 2012; 280: 112-9.

[4] Tucker JM, Schwartz MK, Truex RL, Pilgrim KL, Allendorf FW. Historical and contemporary DNA indicate fisher decline and isolation occurred prior to the European settlement of California. PLoS ONE 2012; 12: e52803.

[5] Spencer W, Rustigian-Romsos H, Strittholt J, Scheller R, Zielinski $\mathrm{W}$, Truex R. Using occupancy and population models to assess habitat conservation opportunities for an isolated carnivore population. Biol Conserv 2011; 144: 788-803.

[6] Truex RL, Zielinski WJ. Short-term effects of fuel treatments on fisher habitat in the Sierra Nevada, California. For Ecol Manage 2013; 293: 85-91.

[7] Zielinski WJ, Truex RL, Schmidt GA, Schlexer FV, Schmidt KN, Barrett RH. Resting habitat selection by fishers in California. J Wildl Manage 2004; 68: 475-92.

[8] He HS, Mladenoff DJ. Spatially explicit and stochastic simulation of forest-landscape fire disturbance and succession. Ecology 1999; 80: 81-99.

[9] Spencer W, Rustigian H, Scheller R, Syphard A, Strittholt J, Ward B. Baseline evaluation of fisher habitat and population status, and effects of fire and fuels management on fishers in the southern Sierra Nevada. Report prepared for USDA Forest Service. Vallejo, CA; Pacific Southwest Region 2008.

[10] Scheller RM, Spencer WD, Rustigian-Romsos H, Syphard AD, Ward BC, Strittholt JR. Using stochastic simulation to evaluate competing risks of wildfires and fuels management on an isolated forest carnivore. Landsc Ecol 2011; 26: 1491-504.

[11] Syphard AD, Scheller RM, Ward BC, Spencer WD, Strittholt JR. Simulating landscape-scale effects of fuels treatments in the Sierra Nevada, California, USA. Int J Wildland Fire 2011; 20: 364-83.

[12] Thompson CM, Zielinski WJ, Purcell KL. Evaluating management risks using landscape trajectory analysis: a case study of California fisher. J Wildl Manage 2011; 75: 1164-76.

[13] Zielinski WJ, Truex RL, Schmidt GA, Schlexer FV, Schmidt KN, Barrett RH. Home range characteristics of fishers in California. J Mammal 2004; 85: 649-57.

[14] Beaty RM, Taylor AH. Spatial and temporal variation of fire regimes in a mixed conifer forest landscape, Southern Cascades, USA. J Biogeogr 2001; 28: 955-66.

[15] Show SB, Kotok EI. The role of fire in California pine forests. Washington, D.C.: United States Department of Agriculture Bulletin 1294, 1924.

[16] Stephenson NL, Parsons DJ, Swetnam TW. Restoring natural fire to the Sequoia-mixed conifer forest: should intense fire play a role? In: Proceedings of the $17^{\text {th }}$ Tall Timbers Fire Ecology Conference, 
May 18-21, 1989. Tall Timbers Research Station, Tallahassee, Florida 1991; pp. 321-7.

[17] Collins BM, Stephens SL. Stand-replacing patches within a "mixed-severity" fire regime: quantitative characterization using recent fires in a long-established natural fire area. Landsc Ecol 2010; 25: 927-39.

[18] Odion DC, Hanson CT. Projecting impacts of fire management on a biodiversity indicator in the Sierra Nevada and Cascades, USA: the black-backed woodpecker. Open For Sci J 2013; 6: 14-23.

[19] Hanson CT, Odion DC. Is fire severity increasing in the Sierra Nevada, California, USA? Int J Wildlland Fire 2013; [in press].

[20] Stephens SL, Martin RE, Clinton NE. Prehistoric fire area and emissions from California's forests, woodlands, shrublands, and grasslands. For Ecol Manage 2007; 251: 205-16.

[21] Bond ML, Lee DE, Siegel RB, Ward, Jr. JP. Habitat use and selection by California spotted owls in a postfire landscape. J Wildl Manage 2009; 73: 1116-24.

[22] Lee DE, Bond ML, Siegel RB. Dynamics of breeding-season site occupancy of the California spotted owl in burned forests. Condor 2012; 114: 792-802.

[23] Wasser SK, Davenport B, Ramage ER, et al. Scat detection dogs in wildlife research and management: application to grizzly and black bears in the Yellowhead ecosystem, Alberta, Canada. Can J Zool 2004; 82: 475-92.

[24] Samuels ML, Witmer JA. Statistics for the life sciences. $3^{\text {rd }}$ ed. Upper Saddle River, New Jersey: Prentice Hall 2003.

[25] Miller JD, Thode AE. Quantifying burn severity in a heterogeneous landscape with a relative version of the delta Normalized Burn Ratio (RdNBR). Remote Sens Environ 2007; 109: 66-80.

[26] Miller JD, Knapp EE, Key CH, et al. Calibration and validation of the relative differenced Normalized Burn Ratio (RdNBR) to three measures of fire severity in the Sierra Nevada and Klamath Mountains, California, USA. Remote Sens Environ 2009; 113: 645-56.

[27] Zielinski WJ, Baldwin JA, Truex RL, Tucker JM, Flebbe PA. Estimating trend in occupancy for the southern Sierra fisher Martes pennanti population. J Fish Wildl Manage 2013; 4: 3-19.

[28] Zielinski WJ, Duncan NP, Farmer EC, Truex RL, Clevenger AP, Barrett RH. Diet of fishers (Martes pennanti) at the southernmost extent of their range. J Mammal 1999; 80: 961-71.

[29] Bond ML, Lee DE, Siegel RB, Tingley MW. Diet and home-range size of California spotted owls in a burned forest. West Birds 2013; 44: 114-26.

[30] Donato DC, Campbell JL, Franklin JF. Multiple successional pathways and precocity in forest development: can some forests be born complex? J Veg Sci 2012; 23: 576-84.

[31] Powers EM, Marshall JD, Zhang J, Wei L. Post-fire management regimes affect carbon sequestration and storage in a Sierra Nevada mixed-conifer forest. For Ecol Manage 2013; 291: 268-77.

[32] Donato DC, Fontaine JB, Kauffman JB, Robinson WD, Law BE. Fuel mass and forest structure following stand-replacement fire and post-fire logging in a mixed-evergreen forest. Int J Wildland Fire 2013; 10.1071/WF12109.

[33] Aubry KB, Raley CM, Buskirk SW, et al. Meta-analyses of habitat selection by fishers at resting sites in the Pacific coastal region. J Wildl Manage 2013; 77: 965-74.

[34] DellaSala DA, Bond ML, Hanson CT, Hutto RL, Odion DC. Complex early seral forests of the Sierra Nevada: what are they and how can they be managed for ecological integrity? Nat Areas J 2013; [in press].

[35] Hanson CT, North MP. Postfire woodpecker foraging in salvage logged and unlogged forests of the Sierra Nevada. Condor 2008; 110: 777-82.

[36] Burnett RD, Taillie P, Seavy N. Plumas-Lassen Administrative Study terrestrial bird module: 2009 monitoring report. In: Plumas Lassen Study 2009 Annual Report. Vallejo, CA: U.S. Forest Service, Pacific Southwest Research Station 2010; pp. 9-41.

[37] Swanson ME, Franklin JF, Beschta RL, et al. The forgotten stage of forest succession: early-successional ecosystems on forest sites. Front Ecol Environ 2011; 9: 117-25.

[38] Buchalski MR, Fontaine JB, Heady III PA, Hayes JP, Frick WF. Bat response to differing fire severity in mixed-conifer forest California, USA. PLoS ONE 2013; 8: e57884.

[39] USFS. Timber Survey Field Notes, 1910-1912, U.S. Forest Service, Stanislaus National Forest. Record Number 095-93-045. San Bruno, California, USA: National Archives and Records Administration - Pacific Region 1910-2.

[40] Leiberg JB. Forest conditions in the northern Sierra Nevada, California. USDI Geological Survey, Professional Paper No. 8 . Washington, D.C: U.S. Government Printing Office 1902.

[41] Bekker MF, Taylor AH. Fire disturbance, forest structure, and stand dynamics in montane forest of the southern Cascades, Thousand Lakes Wilderness, California, USA. Ecoscience 2010; 17: 59-72.

[42] Zielinski WJ, Truex RL, Schlexer FV, Campbell LA, Carroll C. Historical and contemporary distribution of carnivores of the Sierra Nevada, California, USA. J Biogeogr 2005; 32: 1385-407.

[43] Show SB, Kotok EI. Fire and the forest (California pine region). Washington, D.C.: United States Department of Agriculture Department Circular 358, 1925.

[44] Robertson BA, Hutto RL. Is selectively harvested forest an ecological trap for olive-sided flycatchers? Condor 2007; 109: 10921.

[45] Hutto RL. The ecological importance of severe wildfires: some like it hot. Ecol Appl 2008; 18: 1827-34.

[46] Lawler JJ, Safford HD, Girvetz EH. In: Aubry KB, Zielinski WJ, Raphael MG, Proulx G, Buskirk SW, Eds. Biology and conservation of martens, sables, and fishers: a new synthesis. Ithaca, New York: Comstock Publishing Associates 2012; pp. 37197.

[47] Miller JD, Collins BM, Lutz JA, Stephens SL, van Wagtendonk JW, Yasuda DA. Differences in wildfires among ecoregions and land management agencies in the Sierra Nevada region, California, USA. Ecosphere 2012; 3: Article 80.

[48] Odion DC, Hanson CT. Fire severity in conifer forests of the Sierra Nevada, California. Ecosystem 2006; 9: 1177-89.

[49] Odion DC, Hanson CT. Fire severity in the Sierra Nevada revisited: conclusions robust to further analysis. Ecosystem 2008; 11: 12-5.

[50] Van Wagtendonk JW, Van Wagtendonk KA, Thode AE. Factors associated with the severity of intersecting fires in Yosemite National Park, California, USA. Fire Ecol 2012; 8: 11-32.

[51] Carroll C, Spencer WD, Lewis JC. In: Aubry KB, Zielinski WJ, Raphael MG, Proulx G, Buskirk SW, Eds. Biology and conservation of martens, sables, and fishers: a new synthesis. Ithaca, New York: Comstock Publishing Associates 2012; pp. 42950 . 